\title{
Treatment Capability and Microbial Community of Anammox Process Using PVA Gel Beads as Biomass Carriers
}

\author{
ZHIGANG LI ${ }^{1}$, DAISUKE HIRA², TAKAO FUJII², and KENJI FURUKAWA ${ }^{1}$ \\ ${ }^{1}$ Graduate School of Science and Technology, Kumamoto University, \\ /2-39-1 Kurokami, Kumamoto, 860-8555, Japan \\ ${ }^{2}$ Department of Applied Life Science, Faculty of Engineering, Sojo University, \\ 14-22-1 Ikeda, Kumamoto 860-0082, Japan
}

\begin{abstract}
The start-up and treatment ability of a stirred tank anammox reactor (STAR) using PVA gel as biomass carrier were systematically investigated. PVA gels, as a new kind of biomass carrier, exhibited satisfactory treatment ability. Experimental results showed that a maximum nitrogen removal rate of $4.3 \mathrm{~kg} / \mathrm{m}^{3} / \mathrm{d}$ was achieved after 305 days of operation. Different operational strategy indicated that there was limited effect of influent concentration on the treatment ability of the anammox sludge, while the change of HRT has a positive effect on the treatment ability of the anammox sludge. The effluent SS level was relatively low, with an average of about $10 \mathrm{mg} / \mathrm{L}$, which indicated the slight loss of anammox sludge. Stereo microscope and SEM observation showed that anammox sludge gradually and firmly attached on the surface of the PVA gels, showing the effectiveness of PVA gel as the biomass carrier of anammox sludge. DNA analysis showed anammox bacterium KSU-1 was dominant in the annammox reactor, further confirming the effectiveness of using PVA gel bead to culture anammox bacteria.
\end{abstract}

Key words: anammox; PVA gel; nitrogen removal; stirred tank anammox reactor (STAR)

\section{INTRODUCTION}

The anaerobic ammonium oxidation (anammox) is a novel and promising nitrogen removal process which has received considerable attention. ${ }^{1)}$ It involves the oxidation of ammonium under anoxic conditions with nitrite as the electron acceptor and nitrogen gas as the main product. This autotrophic process allows over $50 \%$ of reduction in oxygen supply and no organic carbon supplementation.

However, the application of anammox process is limited by its long start-up periods due to slow growth rates and low biomass yields.. ${ }^{2}$ Another typical drawback is the flotation of anammox granular sludge under high loading rates, which was observed by
Strous et al. ${ }^{3)}$ and many other researchers. As a result, present studies mainly focuse on the development and application of different kinds of biomass carriers. Researchers have shown that biomass carriers are effective in enabling the growth and maintenance of slow-growing micro-organisms and reducing bacterial loss.

In the literature, different types of carrier materials were studied, such as polyester non-woven carriers used by Furukawa, et $a l .^{4)}$, malt ceramics used by Tran et $a l .{ }^{5}$, polyethylene sponge strips used by Zhang et $a l .{ }^{6}$ ), zeolite particles used by Fernández et $a l .{ }^{7)}$, glass beads and sand used by Strous et $a l .{ }^{8)}$ and PEG gel carriers used by Isaka et $a l .{ }^{9}$. . Previously, PVA gel has also been studied as a carrier in Stirred reactor ${ }^{10)}$, 
packed-bed reactor ${ }^{11}$ and fluidized-bed reactor $^{12)}$. It is reported that PVA gel beads have a porous microstructure that allows for microorganisms to penetrate and colonize throughout the gel material, thus providing favorable conditions for retention and cultivation of slowly growing anaerobic microorganisms. ${ }^{10)}$ This study focused on nitrogen removal capacity of stirred tank reactor using PVA gel as a biomass carrier. Results showed that highly concentrated anammox bacteria were attached to the PVA carriers and that stable nitrogen removal rate was achieved.

\section{MATERIALS AND METHODS}

Properties and pretreatment of PVA gels PVA gels supplied by Kuraray Co. (Osaka, Japan) were used in this study as biomass carriers. The PVA gels have a diameter of $4 \mathrm{~mm}$ with a solids content of about $10 \%$ and a specific gravity of 1.025 , making them easy to suspend in water. The PVA gels are hydrophilic in nature and have a porous structure with a continuum of passages 10 to $20 \mu \mathrm{m}$ in throughout each bead. ${ }^{11)}$ Before installing them into the reactor, the PVA gels were exposed in the effluent from an upflow anammox column reactor using nonwoven as biomass carrier in our laboratory ${ }^{13)}$ for about two months, so that anammox bacteria might attach on the PVA gels.

Experimental setup A stirred tank anammox reactor (STAR) was used and the configuration of the reactor is depicted schematically in Fig. 1. The reaction zone was $1.4 l$ and the stirring speed was kept between $70 \sim 120 \mathrm{rpm}$. The reactor was covered with black cloth to avoid light

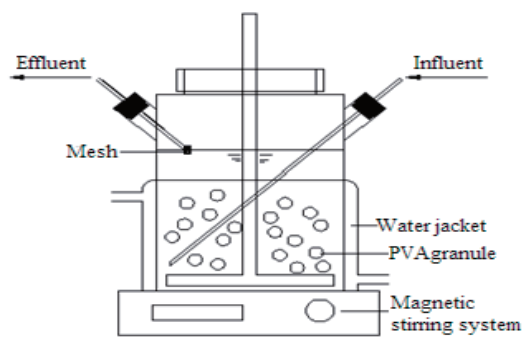

Fig.1. Configuration of reactor used for continuous anammox treatment. inhibition and operated under the temperature of $33-35^{\circ} \mathrm{C}$, thermostatically controlled by a water jacket, and influent $\mathrm{pH}$ of $7.5 \sim 8$. Influent DO concentration was maintained under $0.5 \mathrm{mg} / l$ by flushing the tank with nitrogen gas ${ }^{14}$. The total volume of PVA gels supplied to the reactor was $0.42 l$, accounting for $30 \%$ of the total volume of the reactor.

The reactor was fed with synthetic wastewater consisting of: $\left(\mathrm{NH}_{4}\right)_{2} \mathrm{SO}_{4}$ (75-380 $\mathrm{mg} / l), \quad \mathrm{NaNO}_{2} \quad\left(75-380 \mathrm{mg} / l, \mathrm{KHCO}_{3} \quad(125\right.$ $\mathrm{mg} / l), \quad \mathrm{KH}_{2} \mathrm{PO}_{4} \quad(54 \mathrm{mg} / l), \quad \mathrm{FeSO}_{4} \cdot 7 \mathrm{H}_{2} \mathrm{O} \quad(9$ $\mathrm{mg} / l), \quad$ EDTA $\cdot 2 \mathrm{Na}(5 \mathrm{mg} / l)$ and a solution $(2 \mathrm{ml} / l)$ of mineral salt ${ }^{1)}$. The ammonium to nitrite molar ratio in the feeding media was fixed at 1.0 .

Analytical methods $\quad \mathrm{NO}_{2}{ }^{-}-\mathrm{N}, \mathrm{NO}_{3}{ }^{-}-\mathrm{N}$ and $\mathrm{NH}_{4}{ }^{+}-\mathrm{N}$ were measured according to standard methods, as set out by the American Public Health Association. ${ }^{15)} \quad \mathrm{NO}_{2}^{-}-\mathrm{N}$ and $\mathrm{NH}_{4}{ }^{+}-\mathrm{N}$ were measured by using the different colorimetric method and $\mathrm{NO}_{3}^{-}-\mathrm{N}$ was analyzed by using the UV spectrophotometric method. $\mathrm{pH}$ and DO were measured by standard electrode method. The concentrations of solids, determined as total suspended solids (TSS) and the fraction corresponding to the biomass as volatile suspended solids (MLVSS) of the sludge were determined according to Standard Methods.

SEM observation The anammox granular sludge was observed using a scanning electron microscope (SEM). Specimen preparation was as follows. Firstly, it was fixed by $2.5 \%$ glutaraldehyde fixative solution and $1 \%$ osmic acid solution, and then washed with phosphate buffer. Secondly, the specimen was exposed to sequential ethanol dehydration (including 10\%, 30\%, $50 \%, 70 \%, 90 \%, 95 \%$ and $99.5 \%)$. After dehydration, it was dried at critical point. Finally, the specimen was sputtered with gold and then examined under a scanning electron microscope (JEOL, JAPAN).

DNA extraction and PCR amplification A sample for 16S rRNA gene analysis was taken from the reactor at day 291. 10 PVA gel beads were first ground with a pestle under liquid nitrogen. Meta-genomic DNA was extracted using an ISOIL kit (Wako, Osaka, Japan) according to the manufacturer's 
instructions. The amplification of 16S rRNA gene was performed with Phusion HighFidelity DNA polymerase (FINNZYMES Finland) using conserved eubacterial primers 6F (forwardprimer: 5'-GGAGAGTTAGATCTT GGCTCAG-3') and 1492r (reverseprimer:5'GGTTACCTTG TTACGACT-3' $)^{16,17)}$. PCR was carried out according to the following thermocycling parameters: $30 \mathrm{~s}$ initial denaturation at $98^{\circ} \mathrm{C}, 25$ cycles of $10 \mathrm{~s}$ at $98^{\circ} \mathrm{C}, 20 \mathrm{~s}$ at $51^{\circ} \mathrm{C}, 35 \mathrm{~s}$ at $72^{\circ} \mathrm{C}$, and $5 \mathrm{~min}$ final elongation at $72^{\circ} \mathrm{C}$. The amplified products were electrophoresed on a $1 \%$ agarose gel and the excised fragments were purified using a Wizard SV Gel and PCR Clean-Up System (Promega, USA).

Cloning and sequencing of 16S rRNA gene The purified fragments were ligated into the EcoRV site of pBluescript II KS+ (Stratagene, USA), and Escherichia coli DH10B was transformed using the constructed plasmids. White colonies including the insert were randomly chosen and the plasmids were extracted by the alkaline method. The nucleotide sequences were determined with a 3130xl genetic analyzer and BigDye terminator v3.1 cycle sequencing kit (Applied Biosystems, USA). The sequences determined in this study were compared with the sequences in the nrdatabase using the basic local alignment search tool (BLAST) program available on the NCBI web site.

\section{RESULTS AND DISCUSSION}

STAR performance According to the nitrogen removal performance of the STAR, the operation could be divided into three phases.

During phase 1 (0-195 days), the reactor was started up by inoculating it with cultivated PVA gels, which accounted for $30 \%$ of the reactor volume. The influent T-N concentration was set to $100 \mathrm{mg} / l$, (Fig. 2) The ratio of influent $\mathrm{NH}_{4}{ }^{+}-\mathrm{N}$ to $\mathrm{NO}_{2}{ }^{-}-\mathrm{N}$ ratio was set to $1: 1$. HRT was set at $10.5 \mathrm{~h}$. The initial NLR set at $0.3 \mathrm{~kg} / \mathrm{m}^{3} / \mathrm{d}$. (Fig. 3) The reactor shows stable and satisfactory treatment performance even when the influent T-N concentration was increased to $160 \mathrm{mg} / l$. The removal efficiencies of $\mathrm{T}-\mathrm{N}$, $\mathrm{NH}_{4}{ }^{+}-\mathrm{N}$ and $\mathrm{NO}_{2}{ }^{-}-\mathrm{N}$ were $86 \%, 98 \%$ and $95 \%$, respectively. (Fig. 4) Therefore, after four days of operation, HRT was reduced to $7 \mathrm{~h}$. NLR increased to $0.5 \mathrm{~kg} / \mathrm{m}^{3} / \mathrm{d}$ spontaneously. Then, the nitrogen removal rate was gradually increased by increasing the influent T-N concentration with HRT of $10.5 \mathrm{~h}$. When the nitrogen loading rate reached to $0.8 \mathrm{~kg} /$ $\mathrm{m}^{3} / \mathrm{d}$, the operation was inhibited. However, the reactor performance was restored very quickly within a week by reducing the influent T-N concentration. Till day 57, the nitrogen loading rate was restored to $0.8 \mathrm{~kg} /$ $\mathrm{m}^{3} / \mathrm{d}$. It could be concluded that reactor has been successfully started up. Hereafter, NLR was increased stepwise and reached $3.49 \mathrm{~kg} /$ $\mathrm{m}^{3} / \mathrm{d}$ on day 185 , with the influent T-N concentration of $400 \mathrm{mg} / l$ and HRT of $2.7 \mathrm{~h}$. The removal efficiencies of T-N, $\mathrm{NH}_{4}{ }^{+}-\mathrm{N}$ and $\mathrm{NO}_{2}{ }^{-} \mathrm{N}$ were $80 \%, 84 \%$ and $92 \%$, respectively.

It should be noted that, no anammox sludge was added to the reactor in the startup phase. However, stereo microscope and SEM observation done on day 41 showed clearly the attachment of anammox biomass on the surface of the PVA gels. (Fig.6e, 6f and $7 \mathrm{~b}$ ) This may indicate that anammox biomass could attach on PVA gel carriers in a relatively short time. In previous study, Strous et al. reported that anammox sludge easily adheres to any solid surface such as the inner surface of a reactor and had used sand particles as carrier material to investigate the growth of anammox sludge. In his study, it took 2-3months to attach anammox biomass onto the surface of the carrier, although a large amount of seed sludge was inoculated.9) Isaka et al. used the immobilized anammox gel using PEG and reported that the nitrogen removal activity increased gradually to $3.4 \mathrm{~kg} / \mathrm{m}^{3} / \mathrm{d}$ on day 67 . The start-up process was faster than this study, but it may be due to the fact that certain amount of seed sludge was entrapped in the carriers. He also reported that the start-up period clearly decreased as the concentration of entrapped anammox sludge was increased. ${ }^{18)}$

However, the high NLR obtained in phase 1 was maintained only for ten days. This situation last for about one month and the treatment ability of the reactor failed to be restored to its former level. Therefore, in 
phase 2 (195-265 days), due to the inhibition caused by the quick increase of influent $\mathrm{NO}_{2}{ }^{-}$ $-\mathrm{N}$ concentration in phase 1 , NLR was reduced to $0.5 \mathrm{~kg} / \mathrm{m}^{3} / \mathrm{d}$ by extending HRT. The influent T-N concentration was decreased to $200 \mathrm{mg} / l$ and was increased step by step with HRT remaining unchanged. Until day 265, the influent T-N concentration increased to the maximum $650 \mathrm{mg} / l$. (Fig. 2) The removal efficiencies of T-N, $\mathrm{NH}_{4}{ }^{-}-\mathrm{N}$ and $\mathrm{NO}_{2}{ }^{-}-\mathrm{N}$ were $75 \%, 75 \%$ and $91 \%$, respectively. (Fig. 4) But NLR was only $1.49 \mathrm{~kg} / \mathrm{m}^{3} / \mathrm{d}$ and increased very slowly. (Fig. 3)

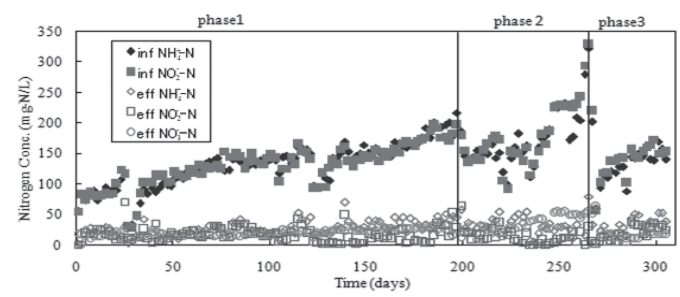

Fig.2. Time courses of influent nitrogen concentrations. Symbols: Closed diamonds, influent $\mathrm{NH}_{4}{ }^{+}-\mathrm{N}$; Closed squares, influent $\mathrm{NO}_{2}^{-}-\mathrm{N}$; Open diamonds, effluent $\mathrm{NH}_{4}{ }^{+}-\mathrm{N}$; Open squares, effluent $\mathrm{NO}_{2}{ }^{-} \mathrm{N}$; Open circles, effluent $\mathrm{NO}_{3}{ }^{-} \mathrm{N}$.

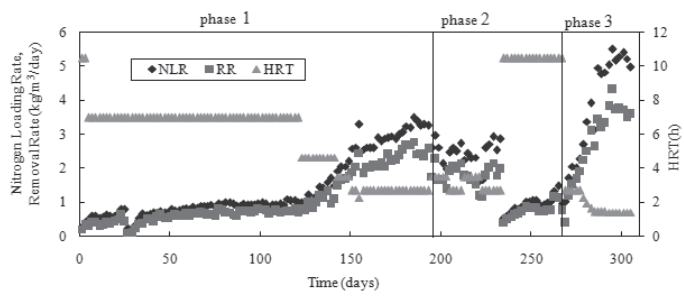

Fig.3. Time courses of HRT, NLR and RR. Symbols: Closed diamonds, NLR; Closed squares, RR; Closed triangles, HRT.

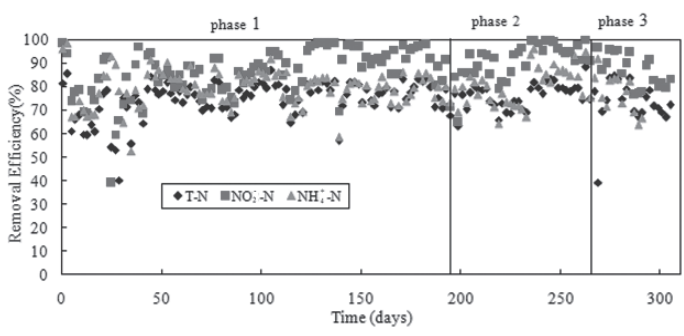

Fig.4. Profile of $\mathrm{T}-\mathrm{N}, \mathrm{NO}_{2}{ }^{-}-\mathrm{N}$ and $\mathrm{NH}_{4}{ }^{+}-\mathrm{N}$ removal efficiencies during the whole operation period. Symbols: Closed diamonds, T-N; Closed squares, $\mathrm{NO}_{2}^{-}-\mathrm{N}$; Closed triangles, $\mathrm{NH}_{4}{ }^{+}-\mathrm{N}$.
This phase showed that it was difficult to enhance the treatment ability of anammox sludge only by increasing the influent T-N concentration. This may indicate that there is limited effect of influent T-N concentration on the treatment ability of the anammox sludge. The result conforms to the research done by Tsushima et al. They reported that there was a limitation to enhance the nitrogen removal rate by only increasing the influent nitrogen concentration at a fixed HRT. ${ }^{5)}$

From phase 3 (265-305days), the influent TN concentration was fixed to $300 \mathrm{mg} / \mathrm{l}$ and NLR was increased stepwise by reducing HRT. After about a month's operation, NLR reached the maximum of $5.5 \mathrm{~kg} / \mathrm{m}^{3} / \mathrm{d}$ on day 295 and NRR was $4.3 \mathrm{~kg} / \mathrm{m}^{3} / \mathrm{d}$. (Fig. 3) The removal efficiencies of $\mathrm{TN}, \mathrm{NH}_{4}{ }^{+}-\mathrm{N}$ and $\mathrm{NO}_{2}{ }^{-}$ -N were $79 \%, 79 \%$ and $91 \%$, respectively. (Fig. 4) NLR could increase very quickly by reducing HRT in phase3. This may indicate that change of HRT has a positive effect on the treatment capacity of anammox sludge. This also confirmed the result reported by Tsushima et al. They reported that the higher nitrogen removal rate was obtained at the shorter HRT. ${ }^{5}$

Variations of effluent SS During the operation, the effluent SS concentrations were relatively stable and were maintained at a low level. (Fig. 5) In phase 1, the effluent SS was below $10 \mathrm{mg} / \mathrm{l}$. In phase 2 and phase 3 , there were slight increases in effluent SS concentration, the highest level being $30 \mathrm{mg} / l$, but the average level was still about $10 \mathrm{mg} / l$. The low effluent SS indicated that most of the anammox sludge was attached firmly on the surface of the PVA gels and the loss of anammox sludge was

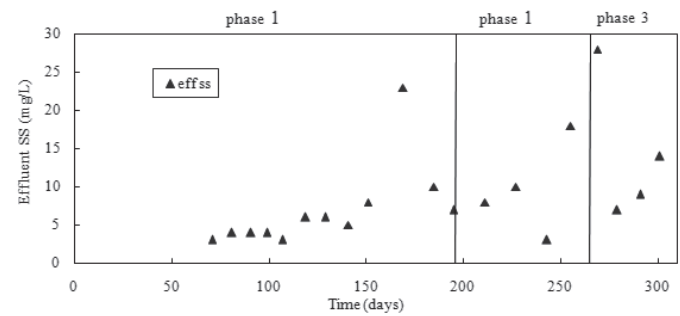

Fig.5. Variations of effluent SS. Symbols: Closed triangles, effluent SS. 
insignificant. It can also be concluded that anammox sludge growing on PVA gels bead could be more easily maintained in the reactor, thus ensuring stable performance of the reactor.

Average reaction ratios of $\mathrm{NH}_{4}{ }^{+}-\mathrm{N}$ removal rate, $\mathrm{NO}_{2}^{-}-\mathrm{N}$ removal rate and $\mathrm{NO}_{3}^{-}-\mathrm{N}$ production rate The reaction ratio of total $\mathrm{NH}_{4}{ }^{+}-\mathrm{N}$ consumption, $\mathrm{NO}_{2}^{-}-\mathrm{N}$ consumption and $\mathrm{NO}_{3}{ }^{-}-\mathrm{N}$ production in this study was 1.0:1.13:0.21, which was similar to the previously reported value for the anammox reaction $\quad(1: 1.31 \pm 0.06: 0.22 \pm 0.02)^{22)}$. The slightly lower $\mathrm{NO}_{2}^{-}-\mathrm{N}$ consumption could be attributed to partial nitrification (i.e., conversion of $\mathrm{NH}_{4}{ }^{+}-\mathrm{N}$ to $\mathrm{NO}_{2}^{-}-\mathrm{N}$ ) in the reactor ${ }^{21)}$.

Comparison of anammox activities using PVA gels as carriers It can be seen from Table 1 that most previous studies using PVA gels were inoculated by PVA gels as well as cultivated anammox sludge. Therefore it is difficult to use their studies for comparison. Tran et al. reported that a maximum nitrogen removal of $3.0 \mathrm{~kg} / \mathrm{m}^{3} / \mathrm{d}$ was obtained in a fluidized bed reactor using PVA gel beads without adding anammox sludge to the reactor. However, it took more than one year for the anammox biomass to attach to the surface of the beads, much longer than this study (two-month pretreatment and about one-month operation), and it took more than 600 days to obtain the maximum nitrogen removal rate of $3.0 \mathrm{~kg} /$ $\mathrm{m}^{3} / \mathrm{d}$, while in this study, a maximum nitrogen removal rate of $4.3 \mathrm{~kg} / \mathrm{m}^{3} / \mathrm{d}$ was obtained after 295 days' continuous operation. ${ }^{19)}$

In previous reports, anammox enriched sludge with different carriers, such as PVA gel beads, glass beads and PEG gel cubes, was used to start up the anammox reactor. Table 1 lists the immobilization methods and nitrogen removal performance in different anammox reactors.

Tran et al. showed that a successful nitrogen removal maximum of $3 \mathrm{~kg}$ was obtained in a fluidized bed reactor using PVA gel beads. However, it took more than one year to attach the anammox biomass to the surface of PVA gel beads in a packed-bed reactor and consequently, it took 500 days to reach this high removal rate in the fluidized bed reactor. On the other hand, isaka et al. used PEG gels for whole cell entrapment of anammox sludge. they reported that it took 67 days and 25days to obtain a removal rate of 3.7 with an initial anammox sludge amount of 0.72 and $4.7 \mathrm{~g}$ dry SS. According to another report, Hsia et al. used the PVA/ alginate immobilization method but only conducted a batch experiment in their study for comparison.

However, the aim of this study and theirs might be different. In this study, a high and stable performance was investigated but the potential maximum nitrogen removal rate after the shortest operational time was their goal. If we operated anammox reactor with their strategy, the same removal performance could be obtained. Besides, a maximum removal rate of $8.2 \mathrm{~kg}-\mathrm{N}$ was confirmed after

Table 1. Comparison of the anammox activities using PVA gels as carriers.

\begin{tabular}{|c|c|c|c|c|c|c|}
\hline Reactor & Carrier & $\begin{array}{l}\text { Influent and } \\
\text { temperature }\left({ }^{\circ} \mathrm{C}\right)\end{array}$ & $\begin{array}{l}\text { Initial sludge } \\
\text { concentration }(\mathrm{g} / l)\end{array}$ & $\begin{array}{l}\text { Operation } \\
\text { time (day) }\end{array}$ & $\begin{array}{l}\text { NRR } \\
\left(\mathrm{kg} / \mathrm{m}^{3} / \mathrm{d}\right)\end{array}$ & Reference \\
\hline Agitation type & PVA gels & Synthetic wastewater, 30 & 0.5 & 168 & 5.5 & Ge et $a l .{ }^{10)}$ \\
\hline STR & $\begin{array}{c}\text { PEG gel } \\
\text { entrapments }\end{array}$ & Synthetic wastewater, 36 & $0.72 \mathrm{~g}$ dry-SS & 67 & 3.7 & Isaka et $a l .^{18)}$ \\
\hline STR & $\begin{array}{c}\text { PEG gel } \\
\text { entrapments }\end{array}$ & Synthetic wastewater, 36 & $4.7 \mathrm{~g}$ dry-SS & 25 & 3.4 & Isaka et $a l .^{18)}$ \\
\hline FBR & PVA gels & Synthetic wastewater, 33-35 & no & 617 & 3.0 & Tran et al. ${ }^{19)}$ \\
\hline STR & $\begin{array}{c}\text { PVA gel } \\
\text { entrapments }\end{array}$ & Synthetic wastewater, 33-35 & $5.0 \mathrm{~g}$ dry-SS & 250 & 8.2 & Quan et $a l .{ }^{20)}$ \\
\hline STAR & PVA gels & Synthetic wastewater, 33-35 & no & 295 & 4.3 & This study \\
\hline
\end{tabular}

FBR: fluidized bed reactor 

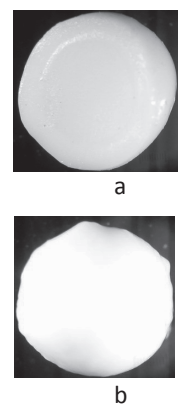

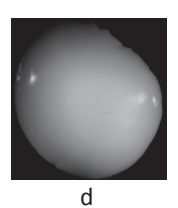

d

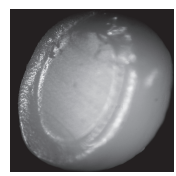

C
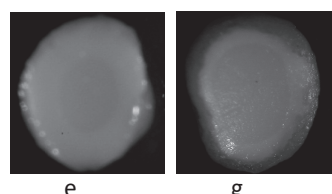

g
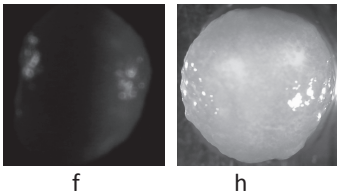

h
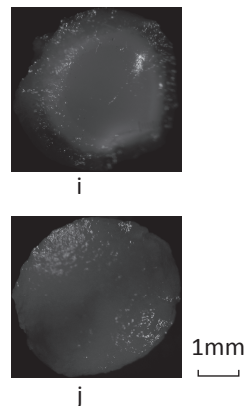

Fig.6. Changes of the PVA gels observed by stereo microscope. a, c, e, g, and i showed the sections of a PVA gel and $b, d, f, h$, and $j$ showed the surfaces of a PVA gel. a and b showed the original gel; $c$ and $d$ showed the gel after two-month pretreatment; e and $f$ showed the gel on day 41; $g$ and $h$ showed the gel on day 155; $\mathrm{i}$ and $\mathrm{j}$ showed the gel on day 280.

250 days of operation in this study. This result demonstrates that whole cell entrapment by PVA gel is one of the most effective techniques for immobilizing anammox bacteria.

Taking into account the above mentioned results, it may be concluded that it is practical to use pre-inoculated PVA gels for getting stable anammox reaction within short periods with PVA gels only and a stable operation result could be obtained.

Macroscopic observation of the PVA gels Fig. 6 illustrated the changes of the PVA gels observed by stereo microscope. Fig. $6 \mathrm{a}$ and $6 \mathrm{~b}$ showed the original gels. They were totally white. After about two months of pre-treatment, changes of the gel surface could be observed but the color changes at this period were not very distinct. (Fig. 6c and $6 \mathrm{~d}$ ) However, after 41 days of continuous operation, the surface of the gels apparently became brown, indicating the attachment of anammox sludge on the gel surface. (Fig. 6e and 6f) Pictures taken on day 155 showed more clearly the red anammox sludge growing on the surface of the PVA gels. (Fig. $6 \mathrm{~g}$ and $6 \mathrm{~h}$ ) The gels became extremely red color till dag 280, and the surface of the gels was smooth and bright, indicating the dense growth of the anammox sludge on the gel surface. (Fig. 6i and 6j) The changes of the thickness of the anammox sludge growing on the surface of the gel were also very striking. The anammox sludge became thicker and thicker with the passage of time.

SEM observation Fig.7 shows the

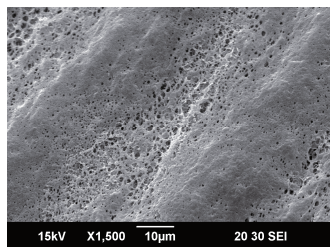

a

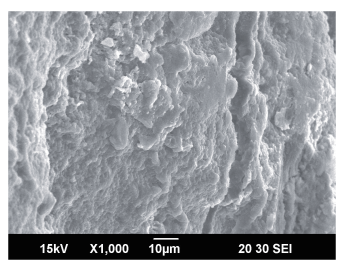

$\mathrm{c}$

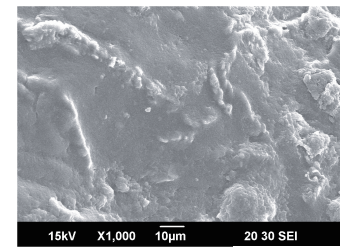

b

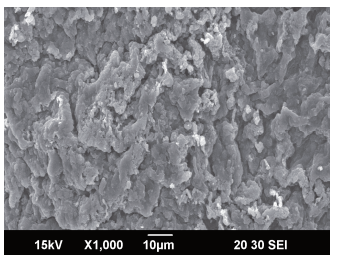

$\mathrm{d}$
Fig.7. Scanning electron microscope (SEM) images of the PVA gel. a showed the surface of a brand new PVA gel; $b$ showed the PVA gel after twomonth pretreatment; c showed the PVA gel on day 41; d showed the PVA gel on day 280.

growth of anammox sludge on the gel surface observed by scanning electron microscope (SEM). The new PVA gels are hydrophilic in nature and have a porous structure with a continuum of passages 10 to $20 \mu \mathrm{m}$ in throughout each bead. The passage is also observable on the surface of the PVA gels. (Fig.7a) After 2 months' pre-treatment, the passages are no longer observed. (Fig.7b) After 41 days' stable operation, the growth of anammox sludge could be easily observed. (Fig.7c) Photo taken on day 280 (Fig.7d) showed that a very thick layer of anammox sludge grew on the surface of the gel and the surface was very smooth with clusters of 
Table 2. Homology search results for $16 \mathrm{~S}$ rRNA gene sequences of the main bacterial members in PVA gel beads.

\begin{tabular}{|c|c|c|c|c|}
\hline OTU & Taxon & Accession & Identity & Number of clones \\
\hline 1 & Planctomycete KSU-1 & $\mathrm{AB} 057453$ & 100 & 8 \\
\hline 2 & $\begin{array}{l}\text { Uncultured bacterium clone: Answdl_02 } \\
\text { Uncultured Planctomycetales bacterium clone DTU1-13 } \\
\text { Candidatus Brocadia anammoxidans }\end{array}$ & $\begin{array}{l}\text { AB594204 } \\
\text { FJ710639 } \\
\text { AF375994 }\end{array}$ & $\begin{array}{l}99 \\
99 \\
94\end{array}$ & 7 \\
\hline 3 & $\begin{array}{l}\text { Uncultured anoxic sludge bacterium KU2 } \\
\text { Candidatus Kuenenia stuttgartiensis }\end{array}$ & $\begin{array}{l}\text { AB054007 } \\
\text { CT5 } 573071\end{array}$ & $\begin{array}{l}100 \\
100\end{array}$ & 1 \\
\hline 4 & $\begin{array}{l}\text { Uncultured bacterium clone T32 } \\
\text { Ignavibacterium album }\end{array}$ & $\begin{array}{l}\text { HM991635 } \\
\text { AB478415 }\end{array}$ & $\begin{array}{l}98 \\
97\end{array}$ & 5 \\
\hline 5 & $\begin{array}{l}\text { Uncultured bacterium clone Dok } 23 \\
\text { Uncultured bacterium clone B18 } \\
\text { Uncultured Chlorobi bacterium clone T12 }\end{array}$ & $\begin{array}{l}\text { FJ710742 } \\
\text { EU888817 } \\
\text { HM991629 }\end{array}$ & $\begin{array}{l}99 \\
99 \\
95\end{array}$ & 1 \\
\hline 6 & $\begin{array}{l}\text { Uncultured bacterium clone: Answdl_03 } \\
\text { Uncultured bacterium clone: A4 } \\
\text { Uncultured Chloroflexi bacterium clone QEDQ2AB09 }\end{array}$ & $\begin{array}{l}\text { AB594205 } \\
\text { AB462405 } \\
\text { CU923588 }\end{array}$ & $\begin{array}{l}98 \\
98 \\
94\end{array}$ & 3 \\
\hline 7 & $\begin{array}{l}\text { Uncultured bacterium clone: AnDHS- } 6 \\
\text { Uncultured bacterium clone S- } 73 \\
\text { Uncultured bacterium clone: AnSal-10 }\end{array}$ & $\begin{array}{l}\text { AB430337 } \\
\text { EF522844 } \\
\text { AB434262 }\end{array}$ & $\begin{array}{l}99 \\
99 \\
99\end{array}$ & 1 \\
\hline
\end{tabular}

Operational taxonomic units (OTUs) were defined by a $1 \%$ distance level in nucleotide sequences

anammox sludge.

Bacteria community analysis In this study, the seed sludge used in the reactor was inoculated from the anammox reactor. The bacterial community was analyzed by using universal eubacterial primers after 291 days of cultivation with synthetic wastewater. Table 2 shows the main results of homology search for 16S rRNA gene sequences in the community existing in PVA gel beads. OUT 1, OUT 2 and OTU 3 had 100\%, 94\% and $100 \%$ sequence identities with Planctomycete KSU-1, Candidatus Brocadia anammoxidans and Candidatus Kuenenia stuttgartiensis, which were detected in the anammox reactors and known to be anammox bacterium. This result shows that the PVA gel bead is useful for culturing these anammox bacteria. Additionally, OUT 6 and OUT 7 had 98\% and $99 \%$ sequence identities with Uncultured bacterium clone: Answdl_03 and Uncultured bacterium clone: AnSal-10, which were also detected in our previous studies ${ }^{23,24)}$. Although the operation strategies of these anammox reactors were quite different, these microbial communities appear to have some similarities. Future studies are needed to investigate the function of the coexistent bacteria.

\section{CONCLUSIONS}

In this study, the STAR reactor was successfully started up by using PVA gels only and a stable operation was obtained within a relatively short period of time. The experimental results showed that the operational strategy was practical and that the PVA gel carrier, as a novel carrier, have great application potential to anammox reactor. Anammox sludge could firmly attach to the surface of the PVA gels and the loss of anammox sludge was insignificant. DNA analysis also confirmed that the PVA gel bead is effective in culturing anammox bacteria with anammox bacteria Planctomycete KSU-1, Candidatus Brocadia anammoxidans and Candidatus Kuenenia stuttgartiensis dominating in the bacterial community.

\section{ACKNOWLEDGEMENTS}

The author is supported by the State Scholarship Fund of China (File No. 2008608040).

\section{REFERENCES}

1 ) Strous M., Heijnen J. J., Kuenen J. G., and Jetten M. S. M.: The sequencing batch 
reactor as a powerful tool for the study of slowly growing anaerobic ammoniumoxidizing microorganisms, Applied Microbiology Biotechnology, 50, 589-596 (1998)

2 ) Jetten, M. S. M., Horn, S. J., and van Loosdrecht, M. C. M.: Towards a more sustainable municipal wastewater treatment system, water science and technology, 35, 171-180(1997)

3 Strous, M., E. van Gerven, Zheng, P., Kuenen, J. G., and Jetten M. S. M.: Ammonium removal from concentrated waste streams with the anaerovic ammonium oxidation (Anammox) process in different reactor configurations, Water Research, 31, 19551962(1997)

4 ) Furukawa, K., Inatomi Y., Qiao S., Quan L., Yamamoto T., Isaka K., and Sumino T.: Innovative treatment system for digester liquor using anammox process, Bioresource Technology, 100, 5437-5443 (2009)

5 ) Tran, H., Luong N. K., Liu Z. J., Fujii T., Kinoshita M., Okamoto H., and Fukawa K.: Anammox treatment performance using malt ceramics as a biomass carrier , Japanese Journal of Water Treatment Biology, 42,159-168 (2006)

6 ) Zhang, L., Yang, J. C., Ma, Y. G., Li, Z. G., Fujii, T., Zhang, W. J., Takashi, N., and Furukawa, K.: Treatment capacity of an up-flow anammox column reactor using polyethylene sponge strips as biomass carrier, Journal of Bioscience and Bioengineering, 110, 72-78 (2010)

7 ) Fernández J. R., Vázquez-Padín, J. R., Mosquera-Corral, A., Campos, J. L., and Méndez, R.: Biofilm and granular systems to improve Anammox biomass retention, Biochemical Engineering Journal, 42, 308-313 (2008)

8 ) Strous M., van Gerven E., Zheng P., Kuenen J. G., and Jetten M. S. M.: Ammonium removal from concentrated waste streams with the anaerobic ammonium oxidation (ANAMMOX) process in different reactor configurations, Water Res, 31, 1955-1962 (1997)

9 ) Isaka K., Date Y., Kimura Y, Sumino T., and Tsuneda S.: Nitrogen removal performance using anaerobic ammonium oxidation at low temperatures, FEMS Microbiol Lett, 282, 32-38 (2008)
10) Ge Y. S., Yamaguchi A., and Sakuma H.: Study on the performance of anaerobic ammonium oxidation treatment using PVA gel as a carrier, Water Science \& Technology, 59, 1037-1041 (2009)

11) Rouse J. D., Fujii T., Sugino H., Tran H., and Furukawa K.: PVA-gel beads as a biomass carrier for anaerobic oxidation of ammonium in a packed-bed reactor, CDROM, In proceedings of $5^{\text {th }}$ International Exhibition And Conference on Environmental Technology, Heleco, 05 (2005)

12) Hoa T. T. H., Khanh N. L., Liu Z. J., Fujii T., Rouse J. D., and Furukawa K.: Nirtogen removal by immobilized anammox sludge using PVA gel as biocarrier, Japanese Journal of Water Treatment Biology, 42, 139-149 (2006)

13) Furukawa, K., Rouse, J. D., Bhatti, Z., Imajo, U., and Ishida, H.: Anaerobic oxidation of ammonium confirmed in continuous flow treatment using nonwoven biomass carrier, Japan J. Water Treat. Biol., 38, 87-94 (2005)

14) Strous M., Gerven, E. van, Kuenen J. G., and Jetten M. S. M.: Effect of aerobic and Microaerobic conditions on anaerobic ammonium-oxidizing (anammox) sludge, Appl. Environ. Microbiol., 63, 2446-2448 (1997)

15) APHA, AWWA, WPCF: Standard Methods for the Examination of Water and Wastewater, 19th ed., American Public Health Association, Washington, DC (1995)

16) Tchelet, R., Meckenstock, R., Steinle, P., and van der Meer, J. R.: Population dynamics of an introduced bacterium degrading chlorinated benzenes in a soil column and in sewage sludge, Biodegradation, 10, 113-125 (1999)

17) Lane, D. J.: $16 \mathrm{~S} / 23 \mathrm{~S}$ rRNA sequencing, in: M. Goodfellow (Ed.), Nucleic Acid Techniques in Bacterial Systematics, Wiley, Chichester, UK, 1991, pp. 115-148 (1991)

18) Isaka K., Date Y., Kimura Y, Sumino T., and Tsuneda S.: Ammonium removal performance of anaerobic ammoniumoxidizing bacteria immobilized in polyethylene glycol gel carrier, Appl. Microbiol. Biotechnol, 76, 1457-1465 
(2007)

19) Tran, T. T. H., Luong, N. K., Liu, Z., Fujii, T., Rouse, J. D., and Furukawa, K.: Nitrogen removal by immobilized anammox sludge using PVA gel as biocarrier, Japanese J. of Water Treat. Biol., 42, 139-149 (2006)

20) Quan, L. M., Liem, T. T., Khanh, D. P., and Furukawa K.: High ammonium wastewater treatment of stirred tank anammox reactor using polyvinyl alcohol/alginate gel as biomass carrier, Japanese J. of Water Treat. Biol., 46, 109-117 (2010)

21) Tsushima, I., Ogasawara, Y., Kindaichi, T., Satoh, H., and Okabe, S.: Development of high-rate anaerobic ammonium-oxidizing (anammox) biofilm reactors, Water Research, 41, 1623-1634 (2007)

22) van de Graaf, A. A., de Bruijn, P., Robertson, L. A., Jetten, M. S. M., and Kuenen, J. G.:
Autotrophic growth of anaerobic ammonium-oxidizing micro-organisms in a fluidized bed reactor, Microbiology, 142, 2187-2196 (1996)

23) Yamamoto T., Wakamatsu S., Qiao S., Hira D., Fujii T., and Furukawa K.: Partial nitritation and anammox of a livestock manure digester liquor and analysis of its microbial community, Bioresource Technology, 102, 2342-2347(2011)

24） Liu C.-L., Yamamoto T., Nishiyama T., Fujii T., and Furukawa K.: Effect of salt concentration in anammox treatment using non-woven biomass carrier, Journal of Bioscience and Bioengineering, 107, 519-523 (2009)

(Submitted 2011.4.28) (Accepted 2011.11.29) 
